\title{
The Utilization of the National Library Website in Southeast Asia
}

\author{
Evi Zakiyah \\ Department of Library and Information Science, Faculty of Adab and Humanities, \\ Syarif Hidayatullah State Islamic University \\ Jakarta, Indonesia \\ evi.zakiyah@uinjkt.ac.id
}

\begin{abstract}
This study was to analyze the National Library websites in Southeast Asia based on population demography and performance of the National Library websites. The webometrics method applied to helps the author to examine the document recorded in the website. 11 countries were chosen, but not all of the National Library websites can be studied because of the lack of maximum development of the national library websites. The findings of this research are that the National Library of Singapore website is at the first rank in the utilization of websites based on population demography, then the second rank is Thailand National Library. Singapore's National Library Website is also tops according to Alexa compared to other National Library website in terms of number of visitors. By this research, it is seen that the utilization of National Library websites in Southeast Asia is still unnoticed and it is unfortunate considering the task and role of the National Library, which should be a role model for other libraries in a country and become a reference to maintain the library's existence in facing competitors in serving the information needs. The origin of this research will be useful for national library administrators as well as the development of library science especially in Webometric study.
\end{abstract}

Keywords-- National Library; Library Website; Webometrics Method

\section{INTRODUCTION}

Along with the increasingly massive technological developments, libraries are required to be more active, dynamic, fast, precise and accurate in providing services to its users. The last few decades of technology used in the library is also quite significant because it is one of the things in accordance with the concept of "Library Is The Growing" in which the library is an organization that is always growing and very important. The aim of library is to maintain existence of library role in the face of competitors in serving public information needs. This is as argued by Fatmawati [1] that the needs for information become very important and very decisive at the same time a librarian requires accurate and precise information so that the level of effectiveness and efficiency becomes the parameter of satisfaction of its librarian so as not abandoned by the users in which one of them is by serving the users through the internet.

People are now experiencing changes in meeting their information needs where from some research that people prefer accessing information with information technology rather than having to go to the library. This is a shift in public behavior so it is a task of the national library to bridge this need where the task of the National Library is a library appointed by the state to serve the information needs of the people. To reach the services in the National Library, According to Verma [2], users access the internet through the national library website is one way to meet the information needs.

Research on the National Library websites has ever been conducted by Verma [2], where the sample taken is the National Library websites in South Asia and the result of the research is that the National Library of India has the highest Impact Website Factor. This research is eager to continue studying national library website but it takes samples in Southeast Asia focusing on utilization of National Library websites according to society demography as well as its website performance.

\section{METHOD}

This study used a quantitative method using Webometrics,which Bjorneborn [3] identifies it as a quantitative aspect study of the construction and use of information resources, website structure and technology, or document review recorded on the website. The subject of this research is the National Library websites in Southeast Asia comprising 11 countries i.e. Brunei Darussalam, Indonesia, Laos, Malaysia, Philippine, Singapore, Thailand, Vietnam, Cambodia, Myanmar, and East Timor will be analyzed by using goggle speed to know the speed of library website as well as website informer, the daily visitors who access the websites of the national libraries and page view in the websites. Websites observation were conducted in September 13, 2017. After analyzing the results from the informer 
website, next steps further are to know the utilization of the national library websites and then the daily number of visitors. The data were divided by the number of people of the country. The number of people in Southeast Asia is obtained from http://www.dosenpendidikan.com here is the percentage calculation formula:

Website utilization $=\frac{\text { number of visitors }}{\text { number of population }} \times 100 \%$

From this calculation, the result of the percentage of a national library website utilization of a country will be obtained.

\section{RESULT AND DISCUSSION}

Based on websites observation that have been done by the researcher, the results obtained about National Libraries websites in Southeast Asia are as presented in Table 1.

TABLE 1

UTILIZATION OF NATIONAL LIBRARIES WEBSITES

\begin{tabular}{|l|c|c|c|c|c|}
\hline Country & $\begin{array}{c}\text { Daily } \\
\text { User }\end{array}$ & $\begin{array}{c}\text { Page } \\
\text { View }\end{array}$ & $\begin{array}{l}\text { Alexa } \\
\text { Rank }\end{array}$ & $\begin{array}{c}\text { Page } \\
\text { Speed } \\
\text { Insight } \\
(/ 100)\end{array}$ & $\begin{array}{c}\text { Percentage } \\
\text { of } \\
\text { Websites } \\
\text { Utilization } \\
\text { of National } \\
\text { Libraries }\end{array}$ \\
\hline $\begin{array}{l}\text { Brunei } \\
\text { Darussalam }\end{array}$ & - & - & - & 12 & \\
\hline Indonesia & 2837 & 9080 & 304481 & 61 & 0.0011 \\
\hline Laos & - & - & - & - & - \\
\hline Malaysia & - & - & 386.309 & 4 & - \\
\hline Philippine & 666 & 1532 & 400.000 & - & 0.0006 \\
\hline Singapore & 32.372 & 106828 & 32522 & 25 & 0.58 \\
\hline Thailand & 661 & 13887 & 812690 & 98 & 0.01 \\
\hline Vietnam & 1172 & 2670 & 349698 & - & 0.001 \\
\hline Cambodia & - & - & - & - & - \\
\hline Myanmar & - & - & - & - & - \\
\hline Timor Leste & - & - & - & - & - \\
\hline
\end{tabular}

accessed in 13 September 2017 at www.website.informer.com

The National Library of Malaysia is located at http://www.pnm.gov.my/, it is ranked 386.309th in Alexa. when the researcher opens the website, the website cannot be accessed.
According to the analysis on the Website informer also there is no information about daily visitors on this website. The National Library of Brunei Darussalam has an address at https://www.librarybrunei.gov.bn when analyzed with website informer, no data can be obtained about this national library. The National Library website address of Laos is national library of Laos.net but information about this website has not been indexed on the informer website. The Philippine national library website's address that is nlv.gov.vn/ef/ occupies more than 400,000th rank based on Alexa where visitors every day website reach 666 and its page view is 1532. For the speed of the website when analyzed with page speed insight does not appear. For the National Library website of Singapore, which is https://www.nlb.gov.sg/, based on the above table can be seen that it has the highest rank compared to those of other countries i.e. 32.372 nd and its daily page view reaches 106.828 where its Alexa ranking is 32522 nd. Thailand national library website address is www.nlt.go.th, where the daily visitors of this library website is 661 and the page view is 13887 according to the above table. This Thai library has a ranking of 812690 th and a speed of 98. For the National Library Website of Vietnam has a ranking of 349698th according to Alexa, where number of visitors per day is 1172 and page view by visitors as much as 2670. The Address of national library of Myanmar is http://www.nlm.gov.mm/. When the writer visits the website, its server of the national library is down and the result of the analysis on the website informer is none appearing on this website. It also happens to Cambodia national library, when analyzed using the informer website results it is no data. While East Timor still does not have a national library website because this year they still focus on the physical construction of the librarybuilding.

Based on the calculation of the utilization of the national library websites as in the table, it is found that the national library website of Singapore is the most often accessed by the public with a percentage of 0.58 , while the second highest in terms of number of people who often access the library website is Thailand with a percentage of 0.01 . In addition to the national library website in Southeast Asia which has a rating in Alexa is the National Library of Singapore which reaches to the 32522nd, where Alexa itself is a site that provides complete information about the ranking of websites in the world and this site becomes the reference of people to measure success of the website owned by a particular library, where the smaller the ranking of a website has the better ranking.

Judging from the description above that many of the National Library websites are managed in less than the maximum and this is very different from what has been suggested by Verma [2] that National libraries around the world maintain their websites that are used to offer a variety of information services that are consistent with various activities to the users in meeting their information needs. In addition, the role of national libraries in the digital age as it is now is not easy 
because according to Brindley [4, pp. 464-481]that a national library should provide pivotal supports and services; support for research; preserving cultural and intellectual heritage, providing locus for national cultural identity; support for knowledge economy; support for life-long education and learning; support for community development; support for citizens and leadership for library systems. Seeing the importance of the role and function of the National Library of a nation, it is appropriate that if from now on the National libraries in Southeast Asia in particularly as in this study to consider and build the information resources consistently owned and managed by the national library websites.

\section{IV.CONCLUSION}

From the results of this study, it can be concluded that Singapore is the first rank in the utilization of the national library website by the ratio of the population of the percentage. Besides, this study also finds out that the national libraries in Southeast Asia are less utilized as it is proven from there are still many national libraries do not have a website, lack of maintenance or website development both in terms of service and speed. It is expected that National Libraries are more aware about their websites because this is one way to get closer to users in terms of meeting the information needs. In addition, further research is expected to conduct in relation to webometrics and other libraries in both utilization and other issues.

\section{REFERENCES}

[1] E. Fatmawati, "Pengembangan Sistem Teknologi Perpustakaan Berbasis Web 3.0," J. Perpust., 2015.

[2] M. K. Verma, "A Webometrics analysis of National Libraries website in South Asia.," Ann. Libr. Inf. Stud., vol. 64 , no. 2.

[3] Bjorneborn, L, "Webometrics 2.0 Blogometrics, Wikimetrics, Tagometrics, and Sociometrics Revisited.," R. Sch. Libr. Inf. Sci., 2008.

[4] Brindley, L, "The Role of national libraries in twenty firts century," Bodleian Libr. Rec., vol. 17, no. (6), pp. 464-481, 2002. 